\title{
RHEOLOGICAL PROPERTIES OF SCC IN TERMS OF ITS THIXOTRIOPIC BEHAVIOUR AND ITS INFLUENCE ON FORMWORK PRESSURE
}

\author{
Jacek Golaszewski $^{1}$, Grzegorz Cygan ${ }^{2}$, Michał Drewniok ${ }^{3}$, Adrian Kilijanek ${ }^{4}$ \\ ${ }^{I}$ Department of Building Processes in the Faculty of Civil Engineering at the Silesian University of Technology, \\ Gliwice, Poland \\ ${ }^{2}$ Department of Building Processes in the Faculty of Civil Engineering at the Silesian University of Technology, \\ Gliwice, Poland \\ ${ }^{3}$ Department of Building Processes in the Faculty of Civil Engineering at the Silesian University of Technology, \\ Gliwice, Poland \\ ${ }^{4}$ Department of Building Processes in the Faculty of Civil Engineering at the Silesian University of Technology, \\ Gliwice, Poland
}

\begin{abstract}
Thixotropic behaviour of SCC is not yet fully recognized. Understanding its nature and the factors influencing that effect, will enable to practical use of this phenomenon, especially in the processes related with casting of SCC. Previous studies showed, that SCC formwork pressure isn't as high as the hydrostatic pressure. Knowing the factors influencing thixotropic behavior will allow to optimum use of the formwork, by its proper design, particularly in terms of technology. The paper present methods of measurements and results of rheological properties, including thixotropic stiffening of designed fresh SCC in comparison with its formwork pressure with constant, fast casting speed. The aim of the study was to determine the effect of the type of cement, w/c ratio, chemical admixtures and time on the rheological properties of selected SCC. The aim was also to determine influence of rheological properties on value of SCC formwork pressure. It will allow to better understand and describe the nature of the previously observed decreasing formwork pressure using self-compacting concrete. The rheological characteristic and thixotropic behaviour of SCC were determined by using a rheometer Viskomat XL and technical tests, air content by pressure method and formwork pressure by the element imitating the column with dimensions of $0.20 \times 0.20 \mathrm{~m}$ and a height of $1.20 \mathrm{~m}$ with specially designed pressure sensors.
\end{abstract}

The research was financed by the project No. 0842/B/T02/2011/40 from the National Science Centre and the project "DoktoRIS Scholarship program for innovative Silesia" co-financed by the European Union under the European Social Fund. Research has been done in collaboration with HARSCO Infrastructure Poland.

Keywords: rheological properties of SCC, thixotrophic behaviour of SCC, SCC formwork pressure, $* * *$

\section{INTRODUCTION}

Concrete, as a mixture of cement paste and aggregate, is one of the most commonly used materials in modern construction. The main, but not the only factor determining the properties of concrete, is the quality of the ingredients used in its production.

The durability of concrete determined, inter alia, ongoing changes in the mixture under load during mixing, transporting, placing, casting and finishing (Fig. 1). Those changes are rheological, and are described in detail in [18][13][14][7][2] [5][17][15][19]. To better understand of phenomena occurring in the concrete implementation of the processes is not possible without a thorough understanding of the rheological properties of concrete in conjunction with the changes in the structure. It includes little known yet, socalled, thixotropic effect that intensifies at the rest and persists after re-mixing.
Fresh SCC, is usually characterized by thixotropic behaviour - "fluid memory." In assumption it is a reversible process. 


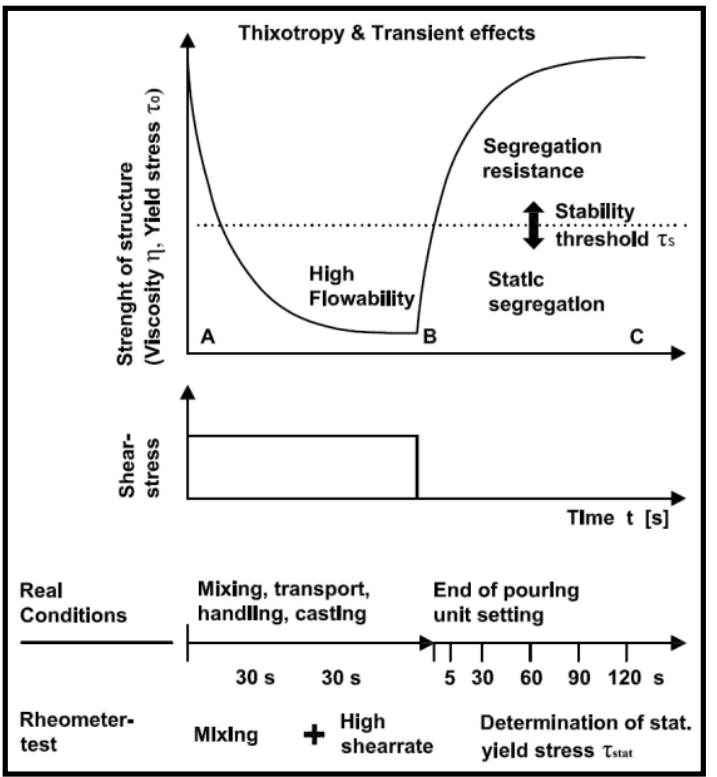

Fig. 1: Rheological parameters of concrete depending on time [15]

It represents the body (liquid) which structure, being at rest, stiffens, followed by a high increase of viscosity. Applying shear stress (supplying energy), over time, the apparent viscosity begins to decrease. This is due to the progressive destruction of the structure through the shear thinning. The rate of disintegration of the bonds depends on amount which can be destructed. After shearing, depending on the number of bonds, structure begins to rebuild [14]. Different types of thixotropic liquid along with their detailed characterization provides, inter alia [11][16][18].

\section{RESEARCH SIGNIFICANCE}

To know the exact moment of structural damage of the mixture, we can specify by the nature of flow curve (Fig. 2a), with the determination of static yield stress at the rest (Fig. 2b). Knowing that mechanism, we could better understand and describe the nature of decreasing formwork pressure using SCC [19]. In case of mortars and fresh concrete, thixotropic effect could be determine by surface area between two flow curves, with increasing and decreasing shear rate - hysteresis loop. It is considered to be representative of the work during the destruction of the thixotropic effect at time and volume unit [17]. However, this is a significant simplification.

It could be, after mixture fully shear thinning. In this case, there will be identical or similar rheological parameters with decreasing shear rate. In the case of concrete mixtures, especially in case of SCC, there is often a loss of workability. This involves a change of rheological parameters of fresh concrete in time. Previous studies e.g. [17][8], show that the hysteresis loop do not show actual values of physical, rheological parameters of fresh concrete. It is not possible, apart from empirical correlations, to determine the effects of the fresh concrete thixotropic properties use hysteresis loop. It could only show the nature of that phenomenon. The experience of the authors indicate that there can be identical or similar field between hysteresis loops with different rheological parameters of different fresh concretes.

Following the definition of thixotropic behaviour, it seems more appropriate to describe of value of thixotropic nature of fresh concrete to determinate a rheological properties of concrete after resting, at a constant, low shear (static yield stress) (Fig. 2b), and with increasing, relatively low shear rate (initial yield stress and initial plastic viscosity). To know the value of thixotropic behavior of SCC, it should be compared these parameters in time, after resting, and also after remixing.

Therefore, the aim of the study was to determine the effect of the type of cement, w/c ratio, chemical admixtures and time on the rheological properties of selected of SCC and also its influence on SCC formwork pressure.

The results will be used to develop a dependence for the calculation of self compacting formwork pressure.

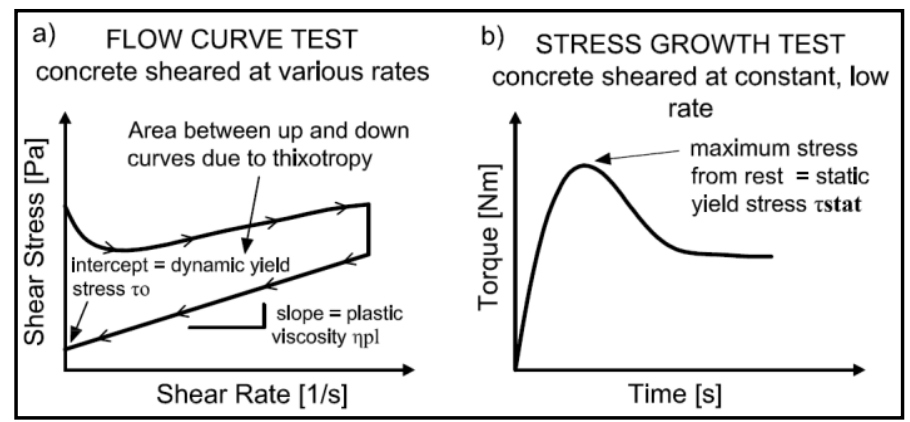

Fig. 2: The flow curve of concrete - determination of the hysteresis loop, c) determination of the static yield stress [15]

\section{EXPERIMENTAL INVESTIGATION}

The scope of the research included:

- to determine the rheological properties of SCC by rheometric (by rheometer Viskomat XL) and technical tests;

- to determine air content in fresh SCC by pressure method;

- to determine SCC formwork pressure at constant casting speed of $7.5 \mathrm{~m} / \mathrm{h}$;

The composition of SCC has been chosen in a manner consistent rheological self-compacting mortar, using the composition of the adjustment based on the assumption of equal values of dispersion for mortar and concrete. The method of calculation is described in detail in [12]. This method relies on the assumption of equality of dispersion ratio of the concrete and cement paste give us the amount of cement mortar which should be in a cement paste after the "removal" of coarse aggregate from concrete. According to the assumptions, all concrete mix contained an identical amount of coarse aggregate and sand, while maintaining a constant value of the sand. The density of cement affected on the amount of cement and water in concrete. The amount of superplasticizer in cement mortars were chosen because of 
their self-consolidating while ensuring stability. The amount of superplastizer in fresh concrete were at the same level as in cement mortars. Superplasticizer has been dose with the mixing water. The mixing time was 5 min (after the addition of mixing water with a chemical admixture).

The rheological parameters of fresh concrete were determined by using a rheometer Viskomat XL. Studies [2][7][13][18] show and it is commonly accepted, that rheological behaviour of fresh concrete may be sufficiently enough described by the Bingham model according to equation:

$$
\tau=\tau_{o}+\eta \cdot \dot{\gamma}
$$

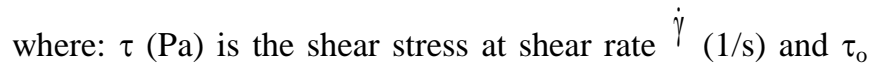
(Pa) and $\eta$ (Pas) are the yield stress and plastic viscosity, respectively.

In rheometry tests, the Bingham model equation (1) is used in its conventional form:

$$
\mathrm{M}=\mathrm{g}+\mathrm{Nh}
$$

where $\mathrm{g}(\mathrm{Nmm})$ and $\mathrm{h}(\mathrm{Nmms})$ are parameters corresponding to Bingham's yield stress and plastic viscosity.

To determine parameters $\mathrm{g}$ and $\mathrm{h}$, was used modified in accordance with[13][10] and [3] described in detail in [2] and [9] rheomertic test procedure. The rotational speed for Viskomat XL and the time of measure are shown in Fig. 3.

The proposed procedure allow to measure the following properties: the static yield stress after first three minute of resting ( $1^{\text {st }}$ static yield stress) (Fig. 3) and $2^{\text {nd }}$ (after second three minutes of resting (the static yield stress was measured at a constant speed of $1 \mathrm{rpm}$ ), the nature of the hysteresis loop, the initial yield stress and initial plastic viscosity with increasing shear rate in a range of speed from 1 to $25 \mathrm{rpm}$ and the dynamic yield stress and plastic viscosity decreasing shear rate (from 25 to $1 \mathrm{rpm}$ ).

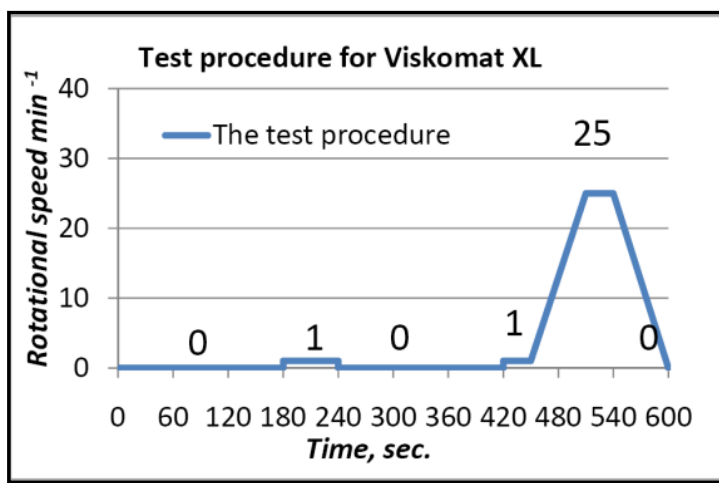

Fig. 3: The rheological test procedure for Viskomat XL

Parallel to the rheometric tests, performed technical tests, according to PN-EN 12350-2, PN-EN 12350-8 for fresh concrete using the Abrams cone (slump-flow test). It was determined the diameter of concrete slump flow and propagation time T500 to a diameter of $500 \mathrm{~mm}$ with an accuracy of $0.1 \mathrm{~s}$ Spreading was carried out using a device for vertical lifting of the cone at a constant speed (Fig. 4).

Tests were determined after mixing ( $\left.0^{\prime}\right)$, after 20 and 40 minutes of resting $\left(20^{\prime}, 40^{\prime}\right)$ and in the 80 minute, after one minute re-mixing $\left(80^{\prime}\right)$. Tests were carried out at constant temperature of $20^{\circ} \mathrm{C}$.

Air content of fresh concrete were made by pressure method in accordance with PN-EN 12350-7. Research performed using the pressure container with a capacity of 8 liters in 1 minute from the end of mixing, after 5 min of rest (Fig. 5). Due to the highly liquid mixtures, it were not used the manual compaction rammer.

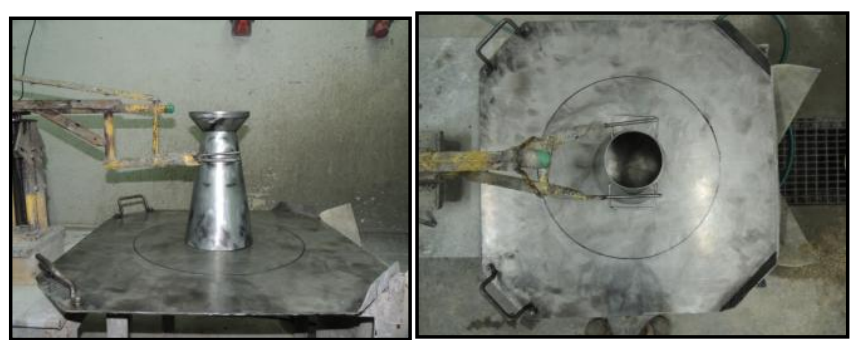

Fig. 4: Technical test equipment for vertical lifting of the cone at a constant speed

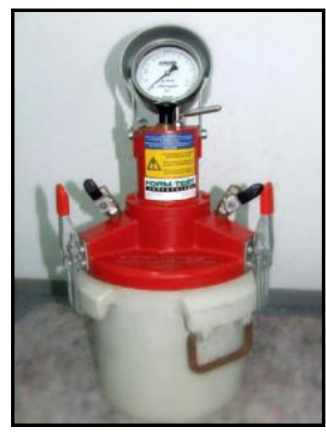

Fig. 5: 8 liters container for the measurement of fresh concrete air content

Measurement of SCC formwork pressure were determined on the element imitating the column with dimensions of $0.20 \times 0.20 \mathrm{~m}$ and a height of $1.20 \mathrm{~m}$. Casting speed were constant and it was $7.5 \mathrm{~m} / \mathrm{h}$. Formwork pressure were measured by pressure sensors with diameter of $87 \mathrm{~mm}$. Pressure was measured from start to the end of casting (every casting took 10 minutes). The pressure sensors were at the bottom of the column, and oppositely, at the height of 0.135 $\mathrm{m}, 0.375 \mathrm{~m}$ and $0.75 \mathrm{~m}$ (from the bottom of the formwork) Fig. 6, Fig. 7. The sensors work with analog and digital computer recording measurements [6]. 


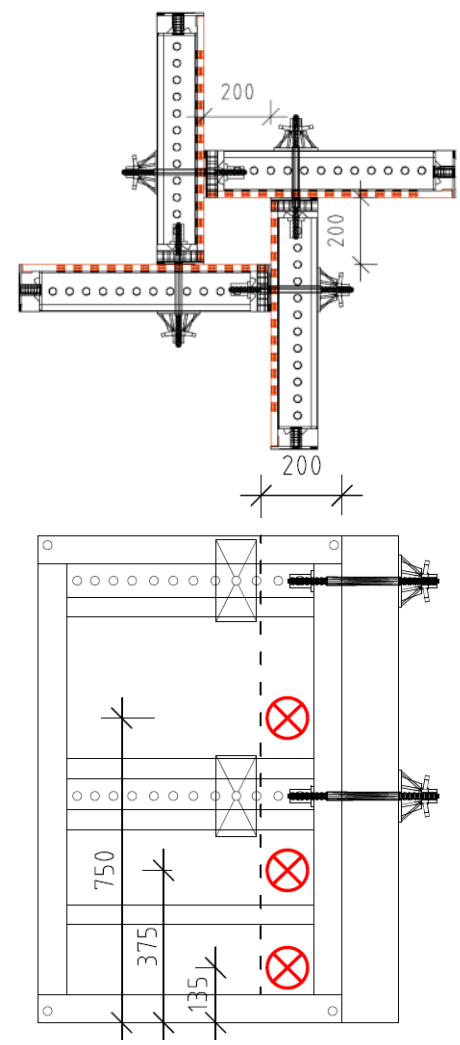

Fig. 6: Laboratory model to determine SCC formwork pressure

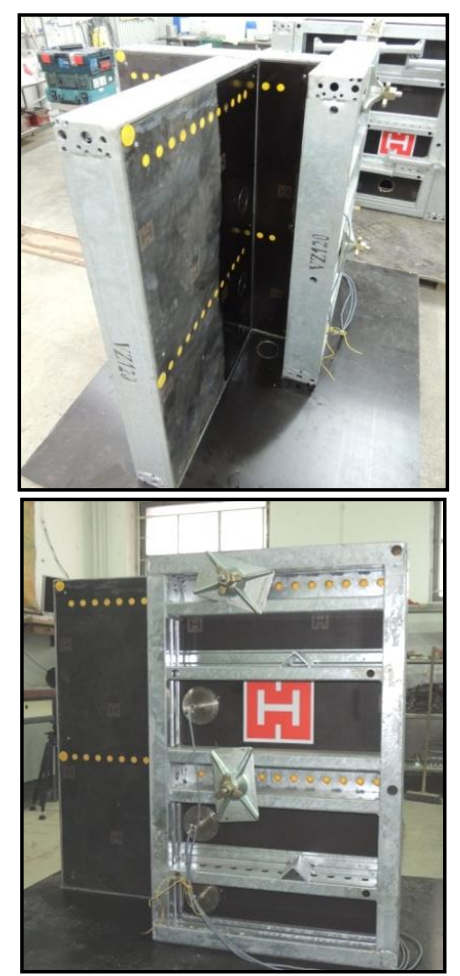

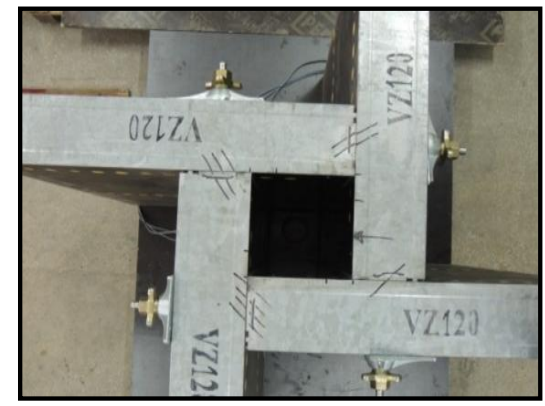

Fig. 7: Laboratory model to determine SCC formwork pressure

\section{MATERIAL PROPERTIES COMPOSITION OF MIXTURES}

For investigation were used:

- Three types of cements (made from the same portland clinker);

- $\quad$ ordinary portland cement CEM I 42.5 R;

- low alkaline, sulphate resistance blast furnace cement, CEM III/A 42.5N-HSR/NA;

- low heat composite cement with granulated blast furnace slag (the same source as in case of CEM III) and fly ash CEM V/A (S-V) 32.5 RLH;

- Two kinds of superplasticizers based on polycarboxylate ether (both as new generation superplastizers):

- PE1 caused good workability in time, high concrete final strenght with very low w/c ratio (for ready mix concrete, precast concrete and shotcrete);

- PE2 with high early and final strength, used with very low w/c ratio and for concrete consistency class from F1 to F6, also for SCC (for precast and pre-stressed concrete);

- $\quad$ sand from Niedomice, near Tarnów and gravel with maximum grain size of $8 \mathrm{~mm}$ from Sieciechowice, near Tarnów.

Aggregate gradation for concrete is shown in Fig. 8.

The composition of concrete and initial properties of fresh concrete are shown in Table 1.

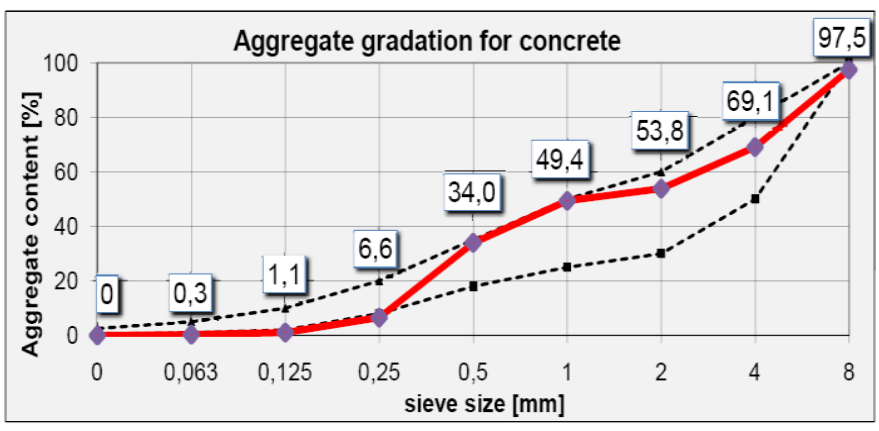

Fig. 8: Aggregate gradation for concrete 
Table 1: The composition of concrete and initial properties of fresh concrete

\begin{tabular}{|c|c|c|c|c|c|c|c|c|c|c|c|}
\hline \multirow{3}{*}{ 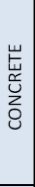 } & 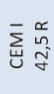 & 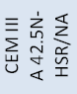 & 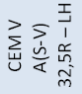 & 离 & $\begin{array}{l}w / c \\
\text { ratio }\end{array}$ & PE co & ntent & $\begin{array}{c}\text { Sand } \\
0-2\end{array}$ & $\begin{array}{c}\text { Coarse } \\
\text { aggregates } \\
2-8\end{array}$ & $\begin{array}{c}\text { Flow } \\
\text { diameter }\end{array}$ & $\begin{array}{l}\text { Flow } \\
\text { time } \\
T_{500}\end{array}$ \\
\hline & \multirow{2}{*}[\mathrm{kg}]{} & \multirow{2}{*}{ [kg] } & \multirow{2}{*}[\mathrm{kg}]{} & \multirow{2}{*}[\mathrm{kg}]{} & \multirow{2}{*}[-]{} & \multicolumn{2}{|c|}{$\begin{array}{l}\text { [\%] weight } \\
\text { of cement }\end{array}$} & \multirow{2}{*}{ [kg] } & \multirow{2}{*}[\mathrm{kg}]{} & \multirow{2}{*}[\mathrm{cm}]{} & \multirow{2}{*}[s]{} \\
\hline & & & & & & PE1 & PE2 & & & & \\
\hline $\begin{array}{c}\mathrm{scc} \\
1 \\
\end{array}$ & 572 & & & 172 & 0.30 & $3.0 \%$ & & \multirow{12}{*}{884} & \multirow{12}{*}{780} & 62.0 & 5.7 \\
\hline $\begin{array}{c}\mathrm{scc} \\
2 \\
\end{array}$ & 508 & & & 203 & 0.40 & $1.0 \%$ & & & & 67.5 & 1.6 \\
\hline $\begin{array}{c}\operatorname{scc} \\
3\end{array}$ & 580 & & & 175 & 0.30 & & $2.0 \%$ & & & 74.5 & 5.9 \\
\hline $\begin{array}{c}\operatorname{scc} \\
4 \\
\end{array}$ & 510 & & & 204 & 0.40 & & $0.75 \%$ & & & 72.0 & 2.2 \\
\hline $\begin{array}{c}\operatorname{scc} \\
5 \\
\end{array}$ & & 573 & & 172 & 0.30 & $1.75 \%$ & & & & 79.5 & 3.5 \\
\hline $\begin{array}{c}\operatorname{scc} \\
6 \\
\end{array}$ & & 502 & & 201 & 0.40 & $0.75 \%$ & & & & 77.0 & 1.6 \\
\hline $\begin{array}{c}\mathrm{SCC} \\
7\end{array}$ & & 579 & & 174 & 0.30 & & $1.0 \%$ & & & 79.5 & 9.8 \\
\hline $\begin{array}{c}\mathrm{scc} \\
8\end{array}$ & & 504 & & 202 & 0.40 & & $0.5 \%$ & & & 74.5 & 1.7 \\
\hline $\begin{array}{c}\mathrm{scc} \\
9 \\
\end{array}$ & & & 555 & 167 & 0.30 & $2.5 \%$ & & & & 74.0 & 6.9 \\
\hline $\begin{array}{c}\text { ScC } \\
10 \\
\end{array}$ & & & 489 & 195 & 0.40 & $1.5 \%$ & & & & 68.0 & 2.5 \\
\hline $\begin{array}{c}\text { scc } \\
11\end{array}$ & & & 559 & 168 & 0.30 & & $2.0 \%$ & & & 74.5 & 6.8 \\
\hline $\begin{array}{c}\text { SCC } \\
12\end{array}$ & & & 493 & 197 & 0.40 & & $0.75 \%$ & & & 69.5 & 3.0 \\
\hline
\end{tabular}

\section{EXPERIMENTAL RESULTS AND}

\section{DISCUSSION}

\subsection{Rheological Properties of SCC Including}

\section{Thixotrophic Behaviour of Fresh Concrete}

\section{Technical Tests}

After 40 minutes of resting, flowability of all fresh concretes with ratio of $w / c=0.3$ decreased (Fig. 9). In case CEM I and CEM III, there were influence of PE. The highest reduction of flowability was in a presence of PE2, unlike in case of CEM V. For that cement, there was slightly smaller reduction of flowability, higher with PE1 lower with PE2. After re-mixing, only CEM I with PE1 characterized by increased workability. The higher loss of workability was in case of CEM III with PE2. The smaller was in case of CEM III, CEM V with PE1 and CEM I with PE2. For CEM V with PE2 workability remained at similar level in comparison with the measurement after mixing.

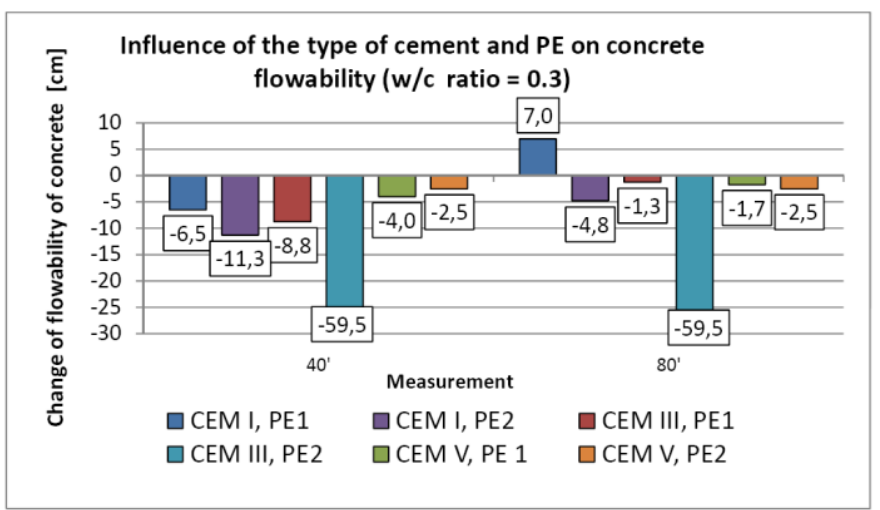

Fig. 9: Influence of the type of cement and PE on concrete flowability $(\mathrm{w} / \mathrm{c}$ ratio $=0.3)$

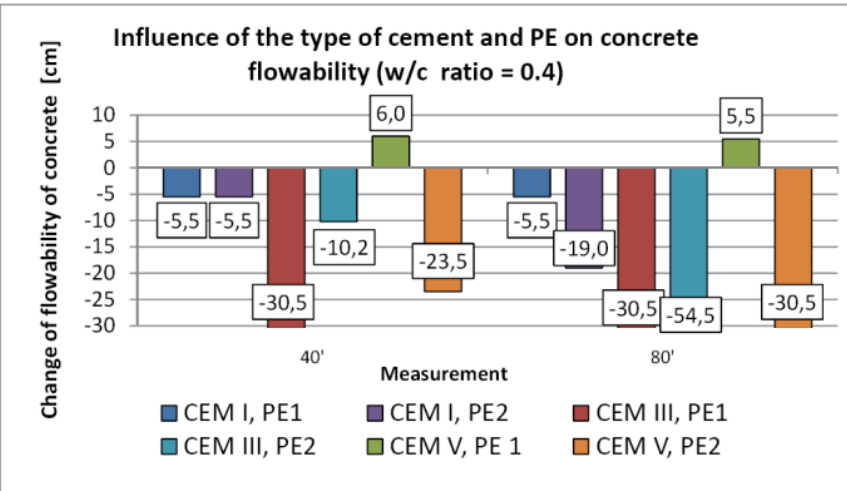

Fig. 10: Influence of the type of cement and PE on concrete flowability $(\mathrm{w} / \mathrm{c}$ ratio $=0.4)$

After 40 minutes of resting, flowability of all fresh concretes with ratio of $w / c=0.4$, except CEM V with PE1, decreased (Fig. 10). For CEM V flowability was higher in comparison with the measurement after mixing. In case CEM I and CEM III, there wasn't influence of PE on concrete flowability (loss of flowability was the same level). The highest reduction of flowability was in case of CEM III and CEM V with PE2.

After re-mixing, none of the mixtures didn't return to the state after mixing. For CEM I and CEM V in a presence of PE1, flowability was at the same level in comparison of 40 min resting. All other characterized by a loss of workability over time, the highest for CEM III with PE2.

Technical tests show, that thixotropic stiffening of SCC may occur in $\mathrm{w} / \mathrm{c}=0.3$ ratio for CEM I, CEM III, CEM V in a presence of PE1 (for CEM V character was smallest). Also for CEM I with PE2, but with a significant loss of workability.

\section{Rheometric tests $-\mathbf{1}^{\text {st }}$ static yield stress}

Because the nature of the $2^{\text {nd }}$ static yield stress was similar to the $1^{\text {st }}$ static yield stress, this paper presents only influence of type of cement and PE on the change $1^{\text {st }}$ static yield stress.

After resting, $1^{\text {st }}$ static yield stress of fresh concrete with ratio of $\mathrm{w} / \mathrm{c}=0.3$, increased $\left(20^{\prime}, 40^{\prime}\right)$ and decreased after remixing (80') (Fig. 11). After $20 \mathrm{~min}$ of resting, the highest increase was in case of CEM I with PE1 and CEM III with PE2. After 40 min of resting the highest increase was in case of CEM I in a presence of PE1 (highest) and PE2 (lowest) and CEM III with PE2. For PE1 with CEM III and CEM V, and PE2 with CEM V increase of the $1^{\text {st }}$ static yield stress was slightly. After re-mixing only CEM I and CEM III in a presence of PE2 didn't return to the state after mixing (0'). For the other value of $1^{\text {st }}$ static yield stress were similar as after mixing, slightly lower for CEM I and CEM V with PE1 and slightly higher for CEM III with PE1 and CEM V with PE2. 


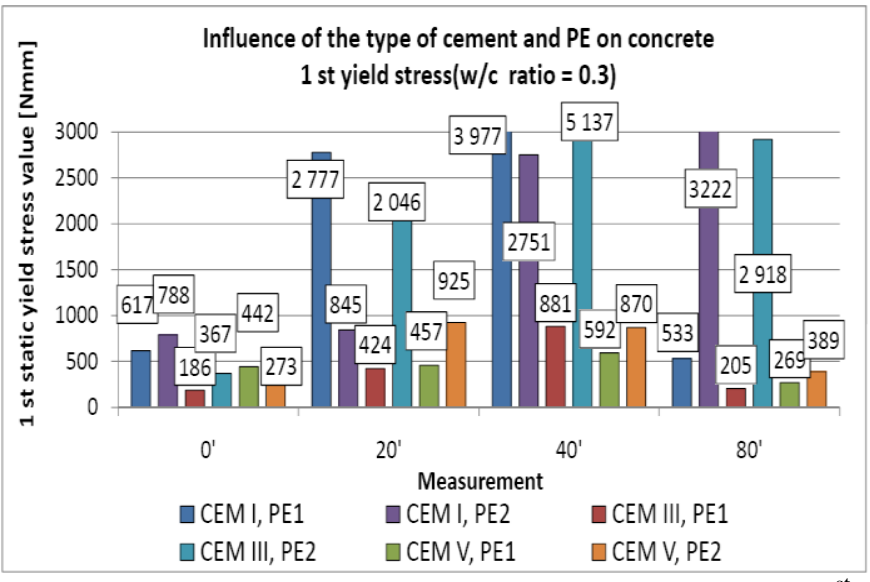

Fig. 11: Influence of type of cement and PE on the change $1^{\text {st }}$ static yield stress $\mathrm{w} / \mathrm{c}$ ratio $=0.3$

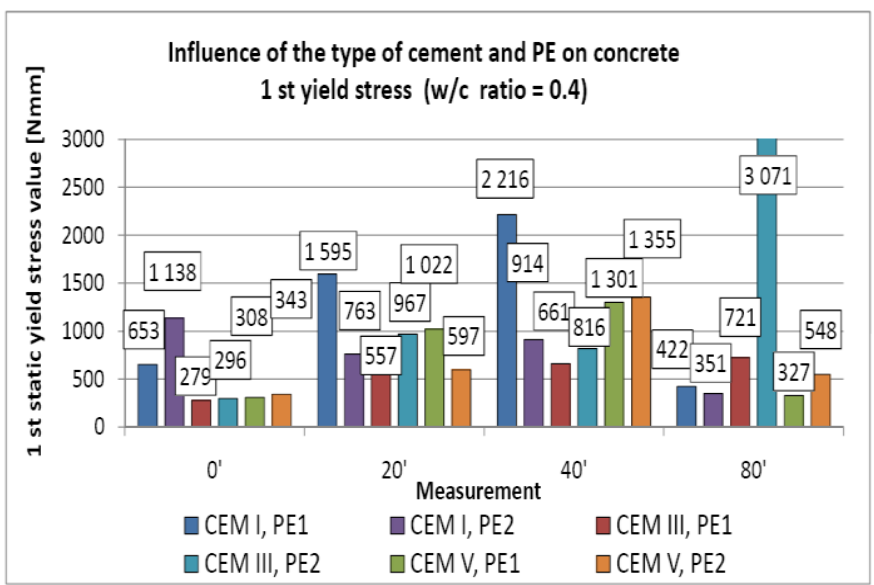

Fig. 12: Influence of type of cement and PE on the change $1^{\text {st }}$ static yield stress $\mathrm{w} / \mathrm{c}$ ratio $=0.4$

After resting, $1^{\text {st }}$ static yield stress of fresh concrete with ratio of $\mathrm{w} / \mathrm{c}=0.4$, increased $\left(20^{\prime}, 40^{\prime}\right)$ and decreased after remixing (80') (Fig. 12). After $20 \mathrm{~min}$ of resting, the highest increase was in case of CEM I with PE1 and CEM III with PE2. After $40 \mathrm{~min}$ of resting the highest increase was in case of CEM I in a presence of PE1 (highest) and PE2 (lowest) and CEM III with PE2. For PE1 with CEM III and CEM V, and PE2 with CEM V increase of the $1^{\text {st }}$ static yield stress was slightly. After re-mixing only CEM I and CEM III in a presence of PE2 didn't return to the state after mixing $\left(0^{\prime}\right)$. For the other value of $1^{\text {st }}$ static yield stress were similar as after mixing, slightly lower for CEM I and CEM V with PE1 and slightly higher for CEM III with PE1 and CEM V with PE2.

Rheometric, $1^{\text {st }}$ static yield stress test shows, that thixotropic stiffening of SCC may occur in case of: $\mathrm{w} / \mathrm{c}=0.3$ ratio for CEM I and CEM III in a presence of PE1. Also for CEM V with PE2, but with a significant loss of workability; $\mathrm{w} / \mathrm{c}=0.4$ ratio for CEM I and CEM V in a presence of PE1. Also for CEM V with PE2, but with a significant loss of workability;

\section{Rheometric Tests - Initial Yield Stress and Initial} Plastic Viscosity

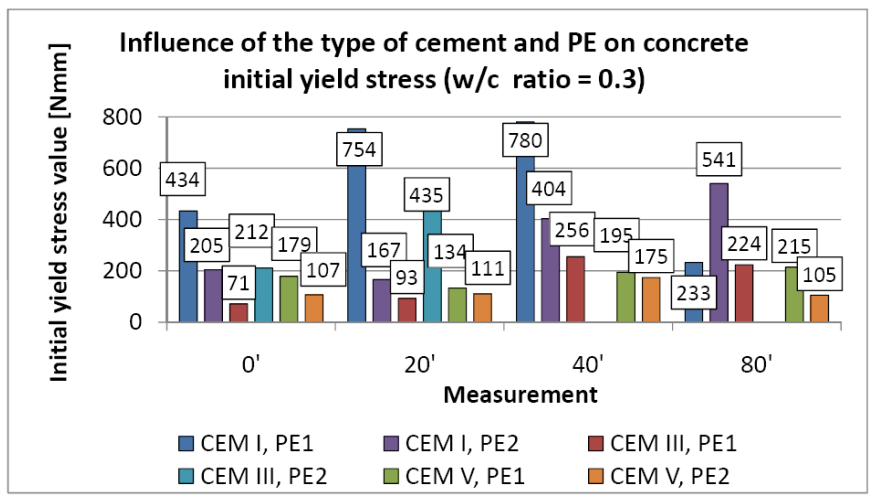

Fig. 13: Influence of type of cement and $P E$ on concrete initial yield stress, $w / c$ ratio $=0.3$

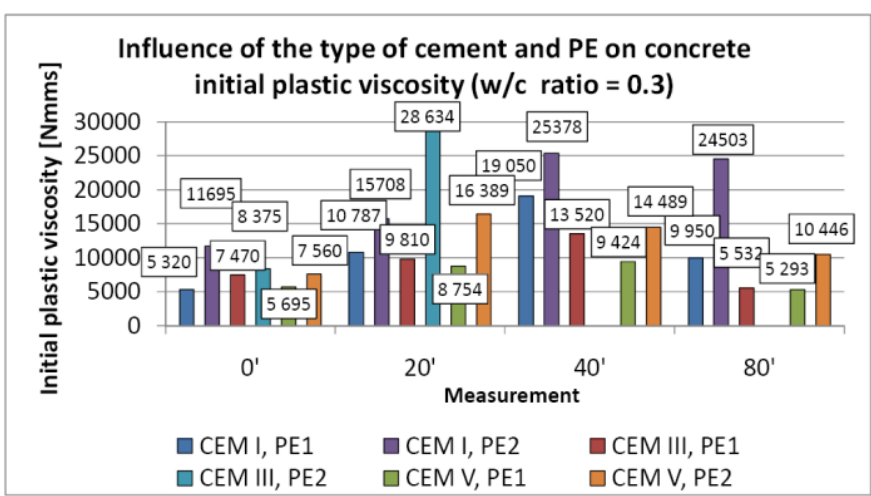

Fig. 14: Influence of the type of cement and $P E$ on concrete initial plastic viscosity, $\mathrm{w} / \mathrm{c}$ ratio $=0.3$

After resting, initial yield stress of almost all fresh concrete with ratio of $w / c=0.3$, increased $\left(20^{\prime}, 40^{\prime}\right)$ (Fig. 13). After 20 min of resting, the highest increase was in case of CEM I with PE1 and CEM III with PE2. In a presence of PE2 with CEM I and PE1 with CEM V initial yield stress slightly decreased. For CEM V with PE2 initial yield stress remained at a constant level. After 40 min of resting the highest value was in case of CEM I in a presence of PE1 (highest) and PE2 (lowest) and for CEM III with PE2 there wasn't ability to measure.

After re-mixing only CEM I and CEM III in a presence of PE2 didn't return to the state after mixing (0'). For CEM I with PE1 value of initial yield stress was lower. For the other value of initial yield stress were similar as after mixing (CEM V), except CEM III with PE1, which value was three times higher.

Initial plastic viscosity of almost all fresh concrete with ratio of $\mathrm{w} / \mathrm{c}=0.3$, increased $\left(20^{\prime}, 40^{\prime}\right)$ (Fig. 14). The highest increase was in a presence of the PE2. For PE1, increase was slightly.

After re-mixing initial plastic viscosity for fresh concretes with PE1, except CEM I, was at the same level as after mixing. 
The highest, which could not be measured, was in case of CEM III with PE2. For that admixture initial plastic viscosity for CEM I was high, at the same level as after 40 minutes of resting. For CEM V value of initial plastic viscosity was higher than after mixing, but lower than after 40 min of resting.

After resting, initial yield stress of almost all fresh concrete with ratio of $w / c=0.4$, increased $\left(20^{\prime}, 40\right.$ ') (Fig. 15) After 20 min of resting, the highest increase was in case of CEM I with PE1 and CEM III with PE2. In a presence of PE2 with CEM I initial yield stress slightly decreased.

After $40 \mathrm{~min}$ of resting the values of initial yield stress slightly increased, highest in case of CEM I with PE1.

After re-mixing only CEM I and CEM $\mathrm{V}$ in a presence of PE1 return to the state after mixing $\left(0^{\prime}\right)$ - for CEM V value of initial yield stress was lower than after mixing. For the other fresh concretes, initial yield stress increased, even in comparison with 40 minutes of rest.

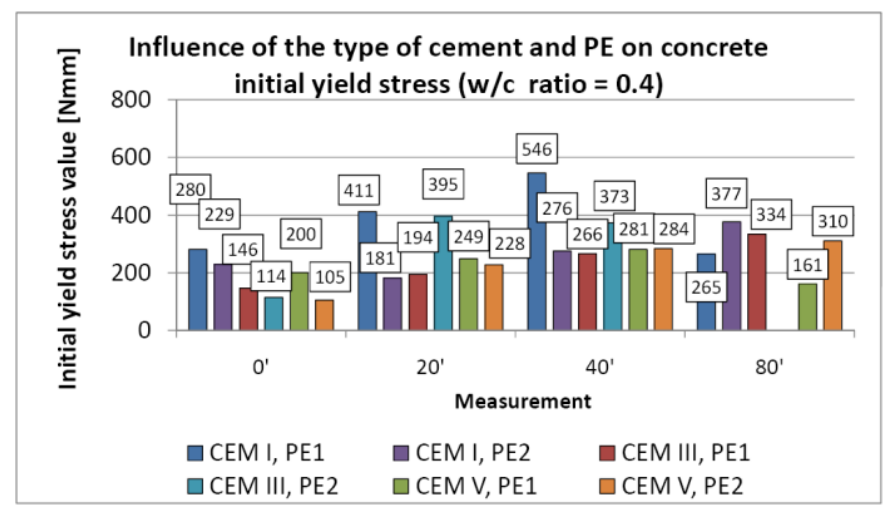

Fig. 15: Influence of type of cement and $P E$ on concrete initial yield stress, $w / c$ ratio $=0.4$

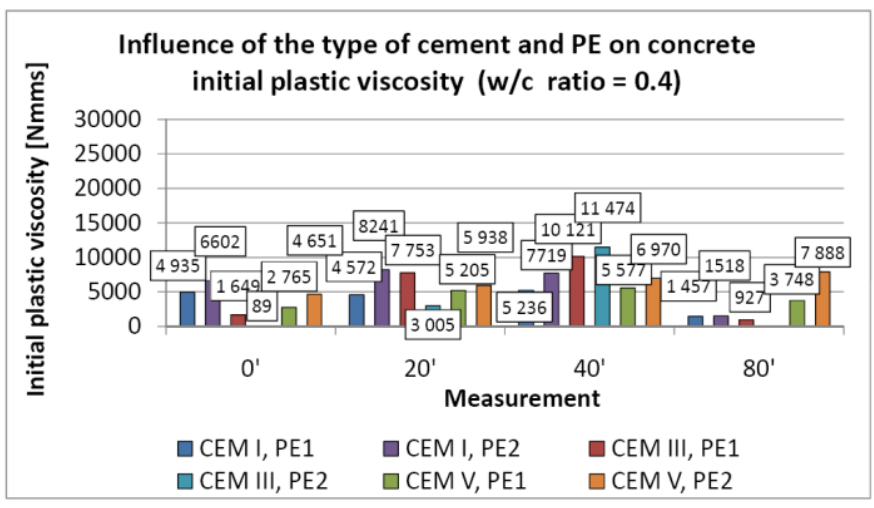

Fig. 16: Influence of the type of cement and PE on concrete initial plastic viscosity, $\mathrm{w} / \mathrm{c}$ ratio $=0.4$

Initial plastic viscosity after mixing in case of PE2 was higher than for PE1 in a presence of CEM I and CEM V (Fig. 16). For CEM I it was highest. Quite the opposite of CEM III. After 20 and 40 minutes of resting initial plastic viscosity increased, slightly in case of CEM V and CEM I, fastest in case of CEM III. After re-mixing only CEM I reduced significantly value of initial plastic viscosity. Less in case of CEM III with PE1. For PE2 there wasn't possibility to measure initial plastic viscosity because of its high value. For CEM V with PE1 initial plastic viscosity was comparable with its value after mixing. For CEM V and PE2 initial plastic viscosity was higher than after mixing and after 40 minutes of resting.

Rheometric, initial yield stress and initial plastic viscosity test shows, that thixotropic stiffening of SCC may occur in case of:

- $\quad$ w/c $=0.3$ ratio for CEM I, CEM III and CEM V in a presence of PE1.;

- $\quad \mathrm{w} / \mathrm{c}=0.4$ ratio for CEM I and CEM V in a presence of PE1;

\subsection{Air Content of SCC}

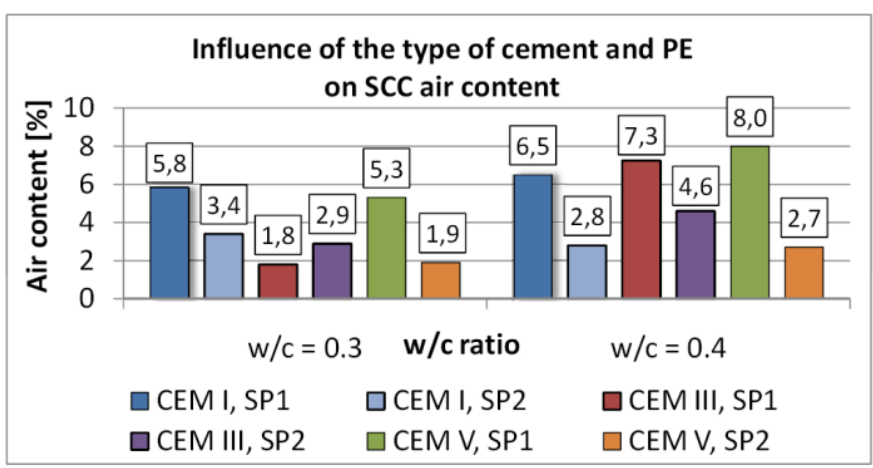

Fig. 17: Influence of the type of cement and PE on concrete air content

Both in the case of w/c ratio of 0.3 and 0.4 were influence of PE on air content in fresh concrete (Fig. 17). PE1 showed secondary effect of admixture which causes aeration of SCC. The exception was in case of CEM III and w/c ratio of 0.3 . PE2 caused higher aeration in case of w/c ratio of 0.4 than 0.3 . For PE2 and w/c ratio of 0.4 air content was slightly greater than on case of 0.3 .

\subsection{Formwork Pressure of SCC at Constant Casting}

\section{Speed}

Formwork pressure of SCC in each cases was lower than hydrostatic pressure. Pressure was lower in the range of $15-$ $30 \%$ of hydrostatic pressure. Similar conclusions are in available literature e.g. [1][2].

In case of w/c ratio of 0.3 and 0.4 , it was comparable.

There wasn't significant influence of type of cement for w/c ratio of 0.3 . For CEM III formwork pressure was slightly lower, higher for CEM I and slightly highest for CEM V. For PE2, SCC formwork pressure was insignificantly higher.

For w/c ratio of 0.4 for CEM III and CEM V in a presence of PE2, SCC formwork pressure was insignificantly higher, unlike in case of CEM I. 


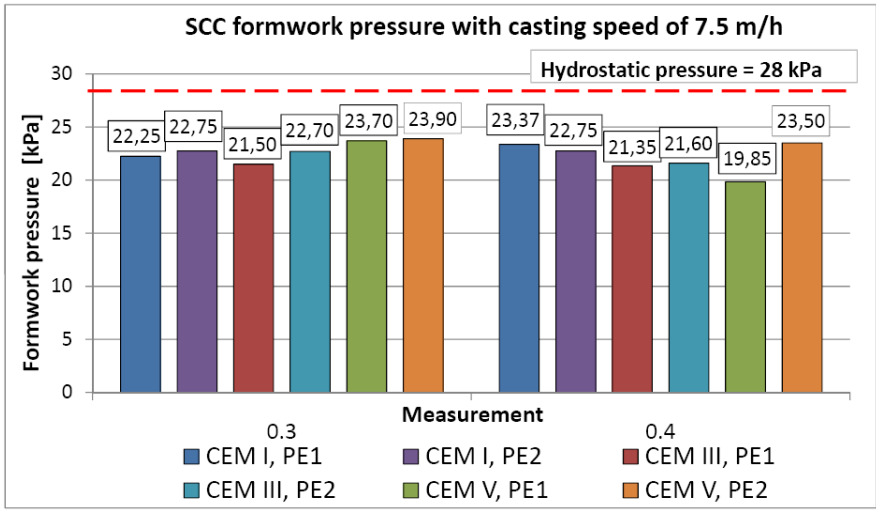

Fig. 18: Influence of the type of cement and PE on SCC formwork pressure with casting speed of $7.5 \mathrm{~m} / \mathrm{h}-$ the lowest sensor

\section{CONCLUSIONS}

The study indicates that the thixotropic stiffening of SCC is very complex phenomenon that requires in-depth knowledge.

Therefore, research in this direction is necessary and should be dealt with using the multi-measurement system. The measurement method of thixotropic stiffening appears to changes of the static yield stress at rest with a change of rheological parameters (initial plastic viscosity and yield stress) determined in the first phase of increasing shear rate, before shear thinning of the mixture.

Based on the performed tests it can be concluded that: workability of concrete in time with lower w/c ratio was better for superplastizer PE1. For CEM V workability with PE1 and PE2 was similar. For higher w/c ratio workability was better also for PE1 but only for CEM I and CEM V. For CEM V was the best;

the thixotropic stiffening of the SCC characterize fresh concrete with a high content of cement with a low coefficient of w/c thereby also relatively high dose of superplasticizer and its type (w/c ratio of 0.3 for CEM I, CEM III and CEM V in a presence of $\mathrm{PE} 1$, in varying intensity);

superplastizer PE1 caused aeration of SCC;

there wasn't significant influence of rheological parameters on formwork pressure (with casting speed of $7.5 \mathrm{~m} / \mathrm{h}$ i.e. in 10 minutes of casting laboratory model).

Rheological parameters, like static yield stress or initial yield stress with initial plastic viscosity are important during slower casting or breaks between casting. This is closely associated with the speed and intensity of formwork pressure reduction, before the beginning of the setting time of cement, for which effect is responsible inter alia thixotropic stiffening of self-compacting concrete.

Open issue is the adoption of a method to estimate which of the effects: thixotropic behaviour or stiffness caused by loss of workability, plays a leading role in the reduction of pressure on formwork. As well as whether the initial yield stress or initial plastic viscosity with different w/c ratio determines the intensity of thixotropy stiffening and reduction of SCC formwork pressure. Verification of the above rheological parameters of SCC, including a thixotropic stiffening and loss of workability, will be during ongoing research of its influence on formwork pressure with slower casting speed and casting after rest.

The research was financed by the project No. 0842/B/T02/2011/40 from the National Science Centre and the project "DoktoRIS - Scholarship program for innovative Silesia" co-financed by the European Union under the European Social Fund. Research has been done in collaboration with HARSCO Infrastructure Poland.

\section{REFERENCES}

[1] Billberg P. (eds): "Casting of Self Sompacting Concrete Report 35," RILEM, Final report of RILEM Technical Commitee 188-CSC 2006

[2] Billberg P.: Form Pressure Generated by SelfCompacting Concrete - Influence of Thixotrophy and Structural Behaviour at Rest. Stockholm, Sweden: Doctoral Thesis, Royal Institute of Technology, 2006

[3] Cheng D.C.-H.: "Thixotrophy," International Jurnal of Cosmetic Science, no. Vol 9.4, pp. 151191, 1987

[4] Drewniok M., Gołaszewski J. Cygan G.: "Consistency of SCC and ist relationship with formwork pressure," in 22. Conference "Rheology of Building Materials", Regensburg, Germany, March, 6th - 7th 2013

[5] Gołaszewski J.: "Technologia betonu samozagęszczalnego a betonu zagęszczanego w sposób tradycyjny," Przegląd Budowlany, pp. 28$36,6 / 2009$

[6] Cygan G., Drewniok M., Gołaszewski J.: "Właściwości mieszanki betonu samozagęszczalnego z cementem wieloskładnikowym," in Konferencja Energia $i$ Środowisko, Szczyrk, 21.-23.05.2014, p. publication in print

[7] Gołaszewski J.: Wplyw superplastyfikatorów na właściwości reologiczne mieszanek na spoiwach cementowych $w$ układzie zmiennych czynników technologicznych. Gliwice: Zeszyty Naukowe Politechniki Śląskiej, 2006.

[8] Gołaszewski J., Drewniok M., and Cygan G.: Właściwości reologiczne mieszanek na spoiwach cementowych $w$ aspekcie efektu tiksotropii. Monografia Politechniki Warszawskiej "Procesy Budowlane". Warszawa: Politechnika Warszawska, 2012, vol. II

[9] Gołaszewski J., Drewniok M., and Cygan G.: "Właściwości reologiczne mieszanki betonowej w aspekcie efektu tiksotropii - procedury badawcze," Technika Transportu Szynowego, no. 9, pp. 19531962, 2012

[10] Helnan-Moussa B., Petit J.Y., Vanhove Y., and Wirquin E.: "Evaluation of the cement paste 
thixotrophy," in Second International Symposium on Design, Performance and Use of SelfConsolidating Concrete, SCC'2009, China, Beijing, China, June 5-7 2009, pp. 526-533

[11] Izak P.: Reologia zawiesin ceramicznych. Kraków: Wyd. AGH, 2012.

[12] Gołaszewski J., Cygan G., and Drewniok M.: "Designing the composition of concrete mixtures based on properties of mortar," in Konferencja „Inżynieria Przedsięwzięć Budowlanych” Kraków, 26-28 VI 2014 - publication in print

[13] Koehler E.P.: "Use Rheology to specify, Design and manage self-consolidating concrete," in 9th ACI International Conference on Superplasticizers \& 10th International Conference on Recent, Seville, Spain, Octobet 2009, pp. 609-623

[14] Kurdowski W.: Chemia Cementu i Betonu. Kraków, Warszawa: Wydawnictwo Polski Cement, Wydawnictwo Naukowe PWN, 2010

[15] Lowke D.: "Superplasticizers and Thixotropy of Fresh Concrete," in 9th ACI International Conference on Superplasticizers \& 10th International Conference on Recent, Seville, Spain, October 2009, pp. 11-37

[16] Migas A.: Reologia ceramicznych zawisin tiksotroowych. Rozprawa dokrotska. Kraków: Katedra Technologii Ceramiki i Materiałów Ogniotrwałych, 2008

[17] Roussel N.: "A thixotrophy model of fresh fluid concretes: theory, validation and applications," Cement and Concrete Research, pp. 1797-1806, 36 (10) 2006

[18] Szwabowski J.: Reologia mieszanek na spowach cementowych. Gliwice: Wydawnictwo Politechniki Śląskiej, 1999

[19] Wallevik E.J.: Rheological properties of cement paste: Thixotropic behavior and structural breakdown., 392009

\section{BIOGRAPHIES:}

Jacek Golaszewski, $\mathrm{PhD}$, is the associated professor at the Department of Building Processes in the Faculty of Civil Engineering at the Silesian University of Technology, Gliwice, Poland. His main research field includes the rheology of cement based materials, the use of admixtures in concrete and the technology of high - performance concrete.

Grzegorz Cygan, MSc., Eng., is a member of $\mathrm{PhD}$ studies at the Department of Building Processes in the Faculty of Civil Engineering at the Silesian University of Technology, Gliwice, Poland. His main research field includes the rheology of cement based materials and the influence of temperature on workability of self-compacting concrete.

Michał Drewniok, MSc., Eng., is a researcher at the Department of Building Processes in the Faculty of Civil Engineering at the Silesian University of Technology, Gliwice, Poland. His main research field includes the rheology of cement based materials, the use of admixtures in concrete and the technology of self-compacting concrete, especially influence of rheological properties of SCC on formwork pressure.

Adrian Kilijanek, BSc., Eng., is a member of MSc. studies at the Department of Building Processes in the Faculty of Civil Engineering at the Silesian University of Technology, Gliwice, Poland. His main research field includes the rheology of cement based materials, properties of hardened concrete and concrete properties at high temperatures (after fires) - SCC, FRC, SCFRC. 